\title{
Assessment of Bacillus thuringiensis subsp. israelensis Strain AM65-52 aqueous suspension for the control of black fly populations, (Simulium spp.) in northern Italy
}

\author{
P. Radeghieri, F. Santi, S. Maini \\ Dipartimento di Scienze Agrarie - Entomologia, Università di Bologna, Italy
}

\begin{abstract}
Four field trials were conducted in Mantua province in northern Italy to evaluate the effect of the Bacillus thuringiensis subsp. israelensis Strain AM65-52 based VectoBac ${ }^{\circledR} 12$ AS larvicide on black flies. Our objective was to examine and compare the efficacy of different concentrations of this microbial larvicide in small plain streams. Larvicidal activity was exhibited in all trials. VectoBac ${ }^{\circledR} 12 \mathrm{AS}$ at $2.5 \mathrm{ppm} / \mathrm{min}$ rate generated larval mortality from the treatment point to 500 meters downstream. Larvae mortality (over 80\%) was observed for 3500
\end{abstract}

Correspondence: Paolo Radeghieri, Dipartimento di Scienze Agrarie (DipSA) - Entomologia, viale Fanin 42, Alma Mater Studiorum Università di Bologna, Italy.

Tel.: +39.051.2096298 - Mobile: 3280217286 .

E-mail: paolo.radeghieri@unibo.it

Acknowledgements: we thank Dr. Heiko Kotter (Valent BioSciences Corporation) for his useful suggestions and financial support.

Key words: black flies control, Simulium paraequinum, Simulium pseudequinum, Simulium erythrocephalum, Bacillus thuringiensis subsp. israelensis, Italy, VectoBac ${ }^{\circledR} 12$ AS.

Contributions: the authors contributed equally.

Conflict of interests: the authors declare no potential conflict of interests.

Funding: this paper reports the results of research only. Mention of a proprietary product does not constitute an endorsement or a recommendation by Alma Mater Studiorum Università di Bologna. The authors express their appreciation to Valent BioSciences Corporation (Libertyville, IL, USA) for providing financial support for this research.

Received for publication: 18 March 2013.

Revision received: 17 June 2013.

Accepted for publication: 7 August 2013.

(C) Copyright P. Radeghieri et al., 2013

Licensee PAGEPress, Italy

Journal of Entomological and Acarological Research 2013; 45:e18

doi:10.4081/jear.2013.e18

This article is distributed under the terms of the Creative Commons Attribution Noncommercial License (by-nc 3.0) which permits any noncommercial use, distribution, and reproduction in any medium, provided the original author(s) and source are credited. meters downstream of the application site when a concentration of 40 $\mathrm{ppm} / \mathrm{min}$ was applied.

\section{Introduction}

A large population of black flies (Diptera: Simuliidae) has been reported for a long time in the basin of the river Mincio (northern Italy). This river is called Sarca before entering lake Garda, and from there it flows approximately $65 \mathrm{~km}$ past Mantua into the Po river. During spring and summer, there is significant tourist activity in this area. Prior to 2009, particularly in the Sigurtà Park (60 ha near the town of Valeggio sul Mincio, Verona province) and other theme parks, black fly outbreaks have been controlled only with insecticide treatments (Santi et al., 2009).

Female black flies are bloodsucking insects that seek blood meals from mammals and birds. Outdoor activities such as gardening and cycling have been severely discouraged due to this host-seeking behavior. In the study area they usually bite cattle and horses; however, bites on humans do occur. Before 2009, large-scale insecticide spray treatments against adults were conducted, with very low efficacy and obvious negative side effects on the environment. After 2009, a biological control project in the Mincio river area against black fly larvae was initiated, and very good efficacy was observed. The program was supported by Peschiera and Valeggio sul Mincio municipalities and private tourism companies. Simulium paraequinum Puri (47.05\%), Simulium pseudequinum Séguy (39.5\%) and Simulium erythrocephalum (De Geer) (13.45\%), were the more common species identified in the study area (Santi et al., 2011). The literature related to occurences in Italy reports that only well-oxygenated, fast-flowing water can support large black fly larvae populations (Rivosecchi \& Coluzzi, 1962; Rivosecchi, 1978; Ghetti et al., 2000; Rivosecchi et al., 2007). Eggs are laid in submerged plants, and newly hatched larvae remain on the leaves. In some cases, they have been also found hidden under the edges of rocks. Larvae are filter feeders, which then pupate, and adults emerging from flowing water then restart the cycle. There can be 4 or 5 generations throughout the year. In our study area, black flies overwinter as larvae.

Good control of a black fly outbreak includes the use of larvicides. The use of products based on Bacillus thuringiensis subsp. israelensis Strain AM65-52 (Bti) against black fly larvae in rivers has been a longtime practice in many countries (Majori et al., 1986; Barjac \& Sutherland, 1990; Riley \& Fusce, 1990; Wegner, 2006; Gray et al., 2012). Multiple studies have found no evidence that Bti applications affected non-target macroinvertebrates or fish (Molloy, 1992; Jackson et al., 1994; McCracken \& Matthews, 1997; Jackson et al., 2002; Bartninkaitè et al., 2006; Bernotiene et al., 2008). The aim of 
this investigation was to study the relative efficacy of Bti on black fly larvae at different rates.

\section{Materials and methods}

Three small streams near Goito (Mantua province, Italy - Stream

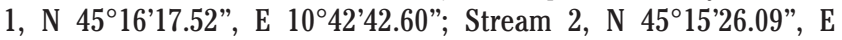

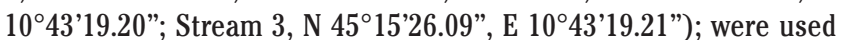
in these experiments. Streams 2 and 3 are flowing parallel, separated by a dam. All streams were treated with bacterial larvicide. VectoBac ${ }^{\circledR} 12 \mathrm{AS}$ (Valent BioSciences Corp., Libertyville, IL, USA) is a suspension concentrate based on the Bacillus thuringiensis subsp. israelensis Strain AM65-52 with a potency of 1200 ITU/mg. Velocity, turbidity, and $\mathrm{pH}$ of the three streams was determined (Tables 1 and 2 ). The larvicide was applied from the river banks using 10-L knapsack sprayers. The larvicide was applied at a single point on 19 August and 22 September 2010, and 27 June and 21 November 2011. The calculated product rate was mixed with 1-2 parts of water to guarantee an application time of approximately 10 minutes at concentrations of $2.5,5$ and $40 \mathrm{ppm} / \mathrm{min}$.

Larvae were collected at specific distances downstream of the application site after the larvicide had passed the collection site. After each application, larvae were collected from six different points (only five points during Trial 2 in Stream 2, Trial 3 in Stream 1 and Trial 4 in Stream 1) with their vegetative substrate, and transferred into a 500 -mL cup. In our study area, the submerged plants were not evenly distributed along the streams, so it was sometimes difficult to collect large numbers of larvae. After sampling in the streams, the cups were placed in a cold icebox. An untreated control sample was collected in the same manner, but 5-100 meters upstream of the application point. After larval collections, the samples were brought to the laboratory and aerated by aquarium pumps for $24 \mathrm{~h}$. Dead and live larvae were counted $24 \mathrm{~h}$ after the Bti treatment.

\section{Results}

\section{Black fly biology and population in study area}

Adults are usually active during early morning, late afternoon and early evening. The mass flight of adults occurred in early April to August in the study area. During the two years of this investigation (2010-2011), it was confirmed that the black flies were overwintering as larvae. Four to five generations were observed. Different larval instars occurred from December to March. Potamogeton crispus L., P. perfoliatus L., P. pectinatus L. and Myriophyllum spicatum L. were the more common plant species collected in the breeding site in which larvae were present.

\section{Trial 1}

Stream 1 was treated with a low concentration of $2.5 \mathrm{ppm} / \mathrm{min}$. High larval mortality was observed initially, with $88.9 \%$ at $150 \mathrm{~m}$, but only $39 \%$ after $400 \mathrm{~m}$ (Tables 1 and 3). After the treatments, in Streams 2 and 3 , very high mortality was observed from the application point to several hundreds meters downstream (Tables 1 and 3 ).

\section{Trial 2}

Larval mortality at the $5 \mathrm{ppm} / \mathrm{min}$ concentration can be directly compared in Streams 2 and 3. Very high larval mortality was observed from the beginning of the treated area to several hundred meters downstream (Tables 1 and 4). At 1100 m downstream of the treatment site, larval mortality was $90.4 \%$ and $93.3 \%$ respectively.

\section{Trial 3}

In Stream 1, treatment with a concentration of $40 \mathrm{ppm} / \mathrm{min}$ produced $100 \%$ larval mortality through $1500 \mathrm{~m}$. Only a few larvae were observed alive through Point 4 (2900 m from the treatment point), with $99.1 \%$ mortality observed. At $3500 \mathrm{~m}$ downstream of the treatment site, $83.6 \%$ mortality was observed (Tables 2 and 5). In Stream 3, a concentration of $5 \mathrm{ppm} / \mathrm{min}$ produced very high mortality (87.1-93.8\%) of black fly larvae through the treatment zone (Tables 2 and 5).

Table 1.Water, stream characteristics and rate of product - Trial 1, 19 August 2010; Trial 2, 22 September 2010.

\begin{tabular}{|c|c|c|c|c|c|c|c|c|c|}
\hline Date & & $\begin{array}{l}\text { Temperature } \\
\left({ }^{\circ} \mathrm{C}\right)\end{array}$ & $\begin{array}{l}\text { Turbidity } \\
\text { FTU }\end{array}$ & $\mathrm{Ph}$ & $\begin{array}{c}\text { Depth average } \\
\text { (m) }\end{array}$ & $\begin{array}{l}\text { Width } \\
\text { (m) }\end{array}$ & $\begin{array}{l}\text { Flow } \\
(\mathrm{m} / \mathrm{s})\end{array}$ & $\begin{array}{c}\text { Discharge } \\
\left(\mathrm{m}^{3} / \mathrm{s}\right)\end{array}$ & $\begin{array}{l}\text { Rate } \\
\text { (L) }\end{array}$ \\
\hline 19 VIII 2010 & Stream 1 & 22.5 & 8.8 & 8.2 & 0.8 & 4.6 & 0.7 & 2.60 & $0.40(2.5 \mathrm{ppm} / \mathrm{min})$ \\
\hline 19 VIII 2010 & Stream 2 & 23.0 & 8.9 & 8.3 & 0.36 & 2.9 & 1.31 & 1.37 & $0.20(2.5 \mathrm{ppm} / \mathrm{min})$ \\
\hline 19 VIII 2010 & Stream 3 & 24.0 & 8.39 & 8.3 & 0.52 & 3.35 & 1.0 & 1.70 & $0.25(2.5 \mathrm{ppm} / \mathrm{min})$ \\
\hline 22 IX 2010 & Stream 2 & 20 & 3.73 & 8.3 & 0.34 & 3.8 & 1.37 & 1.77 & 0.50 (5 ppm/min $)$ \\
\hline 22 IX 2010 & Stream 3 & 20 & 3.73 & 8.3 & 0.36 & 3.8 & 1.38 & 1.92 & $0.50(5 \mathrm{ppm} / \mathrm{min})$ \\
\hline
\end{tabular}

Table 2. Water, stream characteristics and rate of product - Trial 3, 27 June 2011; Trial 4, 21 November 2011.

\begin{tabular}{lccccccccc} 
Date & & $\begin{array}{c}\text { Temperature } \\
\left({ }^{\circ} \mathrm{C}\right)\end{array}$ & $\begin{array}{c}\text { Turbidity } \\
\text { FIU }\end{array}$ & $\begin{array}{c}\text { Ph } \\
\text { Depth average }\end{array}$ & $\begin{array}{c}\text { Width } \\
(\mathrm{m})\end{array}$ & $\begin{array}{c}\text { Flow } \\
(\mathrm{m})\end{array}$ & $\begin{array}{c}\text { Discharge } \\
(\mathrm{m} / \mathrm{s})\end{array}$ & $\begin{array}{c}\text { Rate } \\
(\mathrm{m} / \mathrm{s})\end{array}$ \\
$27 \mathrm{VI} 2011$ & Stream 1 & 23.0 & 7.8 & 8.3 & 0.67 & 4.8 & 0.86 & 2.77 & $6.60(40 \mathrm{ppm} / \mathrm{min})$ \\
$27 \mathrm{VI} 2011$ & Stream 3 & 22.0 & 3.65 & 8.2 & 0.36 & 4.2 & 1.0 & 1.94 & $0.58(5 \mathrm{ppm} / \mathrm{min})$ \\
\hline 21 XI 2011 & Stream 1 & 12.2 & 3.15 & 8.5 & 0.34 & 3.75 & 0.73 & 0.94 & $2.3(40 \mathrm{ppm} / \mathrm{min})$ \\
\hline
\end{tabular}


Table 3. Trial 1 - 19 August 2010 Simuliidae larval mortality treatment with larvicide, rate $2.5 \mathrm{ppm} / \mathrm{min}$.

\begin{tabular}{|c|c|c|c|c|}
\hline & $\begin{array}{c}\text { Sample } \\
\text { distance }(\mathrm{m})\end{array}$ & $\begin{array}{l}\text { No. live } \\
\text { larvae }\end{array}$ & $\begin{array}{l}\text { No. dead } \\
\text { larvae }\end{array}$ & $\begin{array}{c}\text { Mortality } \\
(\%)\end{array}$ \\
\hline \multicolumn{5}{|c|}{ Stream 1} \\
\hline Control & 0 & 569 & 6 & 1.0 \\
\hline Point 1 & 50 & 22 & 49 & 69.0 \\
\hline Point 2 & 100 & 47 & 296 & 86.3 \\
\hline Point 3 & 150 & 7 & 56 & 88.9 \\
\hline Point 4 & 200 & 20 & 58 & 74.4 \\
\hline Point 5 & 300 & 42 & 80 & 65.6 \\
\hline Point 6 & 400 & 82 & 54 & 39.7 \\
\hline \multicolumn{5}{|c|}{ Stream 2} \\
\hline Control & 0 & 480 & 7 & 1.4 \\
\hline Point 1 & 50 & 0 & 38 & 100 \\
\hline Point 2 & 100 & 0 & 21 & 100 \\
\hline Point 3 & 200 & 0 & 35 & 100 \\
\hline Point 4 & 300 & 0 & 13 & 100 \\
\hline Point 5 & 400 & 1 & 17 & 94.4 \\
\hline Point 6 & 500 & 3 & 54 & 94.7 \\
\hline \multicolumn{5}{|c|}{ Stream 3} \\
\hline Control & 0 & 511 & 8 & 1.5 \\
\hline Point 1 & 50 & 5 & 47 & 90.4 \\
\hline Point 2 & 100 & 3 & 38 & 92.7 \\
\hline Point 3 & 200 & 3 & 280 & 98.9 \\
\hline Point 4 & 300 & 8 & 30 & 78.9 \\
\hline Point 5 & 400 & 25 & 73 & 74.5 \\
\hline Point 6 & 500 & 2 & 6 & 75.0 \\
\hline
\end{tabular}

Table 4. Trial 2 - 22 September 2010 Simuliidae larval mortality treatment with larvicide, rate $5 \mathrm{ppm} / \mathrm{min}$.

\begin{tabular}{lcccc} 
Stream 2 & $\begin{array}{c}\text { Sample } \\
\text { distance }(\mathrm{m})\end{array}$ & $\begin{array}{c}\text { No. live } \\
\text { larvae }\end{array}$ & $\begin{array}{c}\text { No. dead } \\
\text { larvae }\end{array}$ & $\begin{array}{c}\text { Mortality } \\
(\%)\end{array}$ \\
Control & 0 & 420 & 2 & 0.5 \\
Point 1 & 350 & 0 & 72 & 100 \\
\hline Point 2 & 550 & 3 & 24 & 88.9 \\
Point 3 & 750 & 4 & 175 & 97.8 \\
\hline Point 4 & 900 & 15 & 158 & 91.3 \\
Point 5 & 1100 & 17 & 161 & 90.4 \\
\hline Stream 3 & & & & \\
\hline Control & 0 & 398 & 1 & 0.2 \\
Point 1 & 200 & 0 & 17 & 100 \\
\hline Point 2 & 350 & 0 & 150 & 100 \\
Point 3 & 550 & 0 & 26 & 100 \\
\hline Point 4 & 750 & 1 & 8 & 88.9 \\
Point 5 & 900 & 0 & 2 & 100 \\
\hline Point 6 & 1100 & 1 & 14 & 93.3 \\
\hline
\end{tabular}

\section{Trial 4}

The concentration of $40 \mathrm{ppm} / \mathrm{min}$ of larvicide generated sufficient Simulium larval mortality several thousand meters downstream in Stream 1 (Tables 2 and 6). Larval mortality was observed (89.4\%) through Point 5 at $3500 \mathrm{~m}$ downstream, even though the water temperature was $12.2^{\circ} \mathrm{C}$, as opposed to all other trials in this stream, which had water temperatures of $20.0-23.0^{\circ} \mathrm{C}$.

\section{Pooled data}

Data from all trials regarding the effects of different concentrations at maximum distances from the treatment points are reported in Figure 1. Only the percent larval mortality at the same sampling distances (Tables 3-6) was analyzed.

\section{Discussion and conclusions}

Larvicide applications conducted at the correct timing of the black flies' cycle reduced the population. At known breeding sites, a well-calculated concentration of larvicide released into the water produces larval mortality and reduces adult black fly numbers. Efficacy of Bti against black fly larvae in the study area was high. The low concentration of 2.5 $\mathrm{ppm} / \mathrm{min}$ generated larval black fly mortality several hundred meters downstream of the treatment site. The concentration of 5 and 40 $\mathrm{ppm} / \mathrm{min}$ of Bti generated Simulium larval mortality in all of these trials. In according with Gray et al. (2012), low water temperature did not affect $B t i$ efficacy. Comparing the November trial at a water temperature of $12.2^{\circ} \mathrm{C}$ with the other trials carried out in summer at $23^{\circ} \mathrm{C}$, demonstrated that water temperature had no effect on larvicide performance. In any case, if low mortality at very low water temperatures (below $10^{\circ} \mathrm{C}$ ) can be seen, it is recommended to use a higher product rate, as indicated on the VectoBac $^{\circledR} 12 \mathrm{AS}$ label, to obtain black fly larval control.

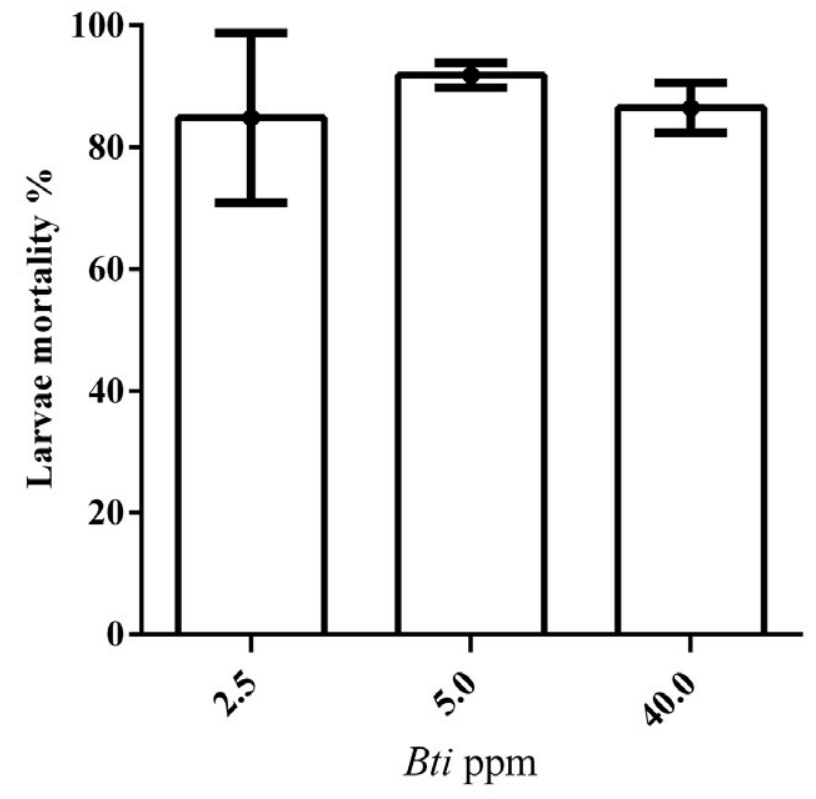

Figure 1. Average \pm standard deviation (SD) larvae mortality at maximum distance from the treatment point. Rates: $2.5 \mathrm{ppm}$ at $500 \mathrm{~m} ; 5 \mathrm{ppm}$ at $1100 \mathrm{~m} ; 40 \mathrm{ppm}$ at $3500 \mathrm{~m}$. 
Table 5. Trial 3 - 27 June 2011 Simuliidae larval mortality treatment with larvicide. Stream 1, rate $40 \mathrm{ppm} / \mathrm{min}$; Stream 3, rate 5 $\mathrm{ppm} / \mathrm{min}$.

\begin{tabular}{lcccc} 
& $\begin{array}{c}\text { Sample } \\
\text { distance }(\mathrm{m})\end{array}$ & $\begin{array}{c}\text { No. live } \\
\text { larvae }\end{array}$ & $\begin{array}{c}\text { No. dead } \\
\text { larvae }\end{array}$ & $\begin{array}{c}\text { Mortality } \\
(\%)\end{array}$ \\
\hline Stream 1 & & & & \\
Control & 0 & 501 & 2 & 0.4 \\
Point 1 & 650 & 0 & 200 & 100 \\
\hline Point 2 & 1500 & 0 & 155 & 100 \\
Point 3 & 2200 & 1 & 206 & 99.5 \\
\hline Point 4 & 2900 & 2 & 218 & 99.1 \\
Point 5 & 3500 & 18 & 92 & 83.6 \\
\hline Stream 3 & & & & \\
\hline Control & 0 & 548 & 2 & 0.4 \\
Point 1 & 500 & 0 & 17 & 100 \\
\hline Point 2 & 800 & 21 & 142 & 87.1 \\
Point 3 & 1000 & 0 & 6 & 100 \\
\hline Point 4 & 1400 & 16 & 244 & 93.8 \\
Point 5 & 1500 & 26 & 282 & 91.6 \\
\hline Point 6 & 1800 & 12 & 183 & 93.8 \\
\hline
\end{tabular}

Table 6. Trial 4 - 21 November 2011 Simuliidae larval mortality treatment with larvicide, rate $40 \mathrm{ppm} / \mathrm{min}$.

\begin{tabular}{lcccc} 
Stream 1 & $\begin{array}{c}\text { Sample } \\
\text { distance }(\mathrm{m})\end{array}$ & $\begin{array}{c}\text { No. live } \\
\text { larvae }\end{array}$ & $\begin{array}{c}\text { No. dead } \\
\text { larvae }\end{array}$ & $\begin{array}{c}\text { Mortality } \\
(\%)\end{array}$ \\
Control & 0 & 545 & 2 & 0.4 \\
Point 1 & 650 & 0 & 300 & 100 \\
\hline Point 2 & 1500 & 8 & 522 & 98.5 \\
Point 3 & 2500 & 11 & 327 & 96.7 \\
\hline Point 4 & 2900 & 7 & 408 & 98.3 \\
Point 5 & 3500 & 38 & 321 & 89.4 \\
\hline
\end{tabular}

The reduction of black fly swarming in the Mincio basin river area after 2009 was significant (Santi et al., 2011). Stakeholders and the general populace have expressed their satisfaction, and also the economic impacts in contrast to other, ineffective pesticide treatments. We hope that, because Bti is an effective and environmentally friendly treatment, we can encourage the adoption of this control practice in other river basins where black fly populations still pose a danger, particularly to horses and cows.

\section{References}

BARJAC H., SUTHERLAND D., 1990 - Bacterial control of mosquitoes and black flies. - Rutgers University Press, New Brunswick, NJ.
BARTNINKAITE I., BERNOTIENE R., PAKALNISKIS S., ZYGUTIENE M., 2006 - Control of bloodsucking black fly (Simuliidae) population in Lithuania. - Ekologija 4: 70-75.

BERNOTIENE R., BARTNINKAITE I., VISINSKIENE G., 2008 - Diffusion of Bacillus thuringiensis bacteria and their effect on aquatic invertebrates in the Nemunas River after using Vectobac 12AS preparation. - Ekologija 54: 93-97.

GHETTI P., TAGLIAPIETRA D., LOSSO C., VOLPI GHIRARDINI A., GHIRELLI L., PEDRON M., RIVOSECCHI L., 2000 - Diffusion of blackfly species (Diptera, Simuliidae) in Friuli Venezia Giulia (Italy). - Ital. J. Zool. 67: 349-353.

GRAY E.W., WYATT R.D., ADLER P.H., SMINK J., COX J.E., NOBLET R., 2012 - The lack of effect of low temperature and high turbidity on operational Bacillus thuringiensis subsp. israelensis activity against larval backflies (Diptera: Simuliidae). - J. Am. Mosq. Control Assoc. 28: 134-136.

JACKSON, J., SWEENEY B., BOTT T., NEWBOLD D., KAPLAN L., 1994 Transport of Bacillus thuringiensis var. israelensis and its effect on drift and benthic densities of nontarget macroinvertebrates in the Susquehanna River, Northern Pennsylvania. - Can. J. Fish. Aquat. Sci. 51: 295-314.

JACKSON K.J., HOROWITZ J.R., SWEENEY B.W., 2002 - Effects of Bacillus thuringiensis israelensis on black flies and nontarget macroinvertebrates and fish in large river. - T. Am. Fish. Soc. 131: 910-930.

MAJORI G., RIVOSECCHI L., MATTASSI G., ROMI R., 1986 - Lotta biologica contro i Simulidi: primo esperimento di lotta con Bacillus thuringiensis $\mathrm{H} 14$ contro Wilhelmia stylata e Boophtora erythrocephala in Friuli Venezia Giulia. - Riv. Parassitol. Ital. 28: 272-273.

McCRACKEN I.R., MATTHEWS S.L., 1997 - Effects of Bacillus thuringiensis subsp. israelensis (B.t.i.) applications on invertebrates from two streams on Prince Edward Island. - Bull. Environ. Contam. Toxicol. 58: 291-298.

MOLLOY D.P., 1992 - Impact of the black fly (Diptera: Simuliidae) control agent Bacillus thuringiensis var. israelensis on chironomids (Diptera: Chironomidae) and other nontarget insects: results of ten field trials. - J. Am. Mosq. Control Assoc. 8: 24-31.

RILEY C., FUSCE R., 1990 - Field efficacy of VectoBac 12AS and VectoBac 24AS against black fly larvae in New Brunswick streams (Diptera: Simuliidae). - J. Am. Mosq. Control Assoc. 6: 42-46.

RIVOSECCHI L., 1978 - Diptera Nematocera Simuliidae. Fauna d'Italia, vol. XIII. - Ed. Calderini, Bologna: 533.

RIVOSECCHI L., COLUZZI M., 1962 - Tre simulidi che in Italia pungono l'uomo. - Parassitologia 4: 181-90.

RIVOSECCHI L., ADDONISIO M., MAIOLINI B., 2007 - I Ditteri Simulidi: nuove chiavi dicotomiche per l'identificazione delle specie italiane con brevi note biotassonomiche.- Quad. Museo Tridentino Sci. Nat 2: 148.

SANTI F., RADEGHIERI P., MIGLIORINI D., MAINI S., 2009 - Popolazioni di ditteri Simulidi nel parco del giardino Sigurtà, Valeggio sul Mincio (VR). - Atti XXII Congr. Naz. Ital. Entomol., Ancona 171.

SANTI F., RADEGHIERI P., MIGLIORINI D., MAINI S., 2011 Contenimento di ditteri simulidi nell'Alto Mincio. - Atti XXIII Congr. Naz. Entomologia, Genova: 359.

WEGNER E., 2006 - Mass occurrences of blackflies (Diptera: Simuliidae) and control actions against them in Poland. - Acta Ent. Serb. Supplement: 155-159. 